Bangladesh J. Plant Taxon. 24(2): 155-164, 2017 (December)

(C) 2017 Bangladesh Association of Plant Taxonomists

\title{
MOLECULAR PHYLOGENY OF SAUDI ARABIAN TETRAENA MAXIM. AND ZYGOPHYLLUM L. (ZYGOPHYLLACEAE) BASED ON PLASTID DNA SEQUENCES
}

\author{
Dhafer Ahmed Alzahrani ${ }^{1}$ and Enas Jameel Albokhari ${ }^{2}$ \\ Department of Biological Sciences, Faculty of Science, King Abdulaziz University, \\ Jeddah, Saudi Arabia.
}

Keywords: cpDNA; rbcL; trnL-F; Phylogeny; Saudi Arabia; Tetraena; Zygophyllum; Zygophyllaceae.

\begin{abstract}
In order to provide a basis for better understanding of phylogenetic relationships of Saudi Arabian Tetraena Maxim. and Zygophyllum L., 44 specimens representing seven taxa, were reconstructed based on chloroplast DNA data of $r b c \mathrm{~L}$ and $t r n \mathrm{~L}-\mathrm{F}$. The combined chloroplast $(r b c \mathrm{~L}$ and $\operatorname{tr} n \mathrm{~L}-\mathrm{F})$ contributed more phylogenetically informative characters than in individual regions. Phylogenetic analysis of the combined chloroplast $(r b c \mathrm{~L}$ and $t r n \mathrm{~L}-\mathrm{F})$ and in individual regions based on both of Maximum Parsimony and Bayesian criteria showed that the Saudi Arabian species of Tetraena and Zygophyllum were monophyletic. Zygophyllum fabag L. was nested in one clade with Z. xanthoxylum (Bunge) Engl. (Asian species), and all taxa of Tetraena were distributed in other clades.
\end{abstract}

\section{Introduction}

The widespread family Zygophyllaceae includes five subfamilies viz. Zygophylloideae, Tribuloideae, Seetzenioideae, Larreoideae and Morkillioideae (Sheahan and Chase, 2000; Beier et al., 2003; Bellstedt et al., 2008). The Zygophyllum L. and Tetraena Maxim. belong to Zygophylloideae along with Fagonia L., Augea Thunb., Roepera (A. Juss.) Engl. and Melocarpum (Engl.) Beier \& Thulin (Beier et al., 2003; Bellstedt et al., 2008).

The only detailed examination of the systematics of Zygophyllum and Tetraena taxa have focused on morphological and anatomical characters (El-Hadidi, 1977, 1980; Boulos, 1978; Engler, 1931; Hosny, 1988; Hussein et al., 2009; Ma and Zhang, 1990; Takhtajan, 1987; Thulin, 1993; Van Huyssteen, 1937; Van Zyl, 2000). In contrast, a few studies have used molecular markers to the phylogenetic relationships of the intergeneric of Zygophyllaceae (Sheahan and Chase, 1996, 2000; Beier et al., 2003) or to infer the relationships within the genus Zygophyllum (Bellstedt et al., 2008; Hammad and Qari, 2010). Sheahan and Chase (1996) studied the phylogenetic relationships of Zygophyllaceae based on morphology, anatomy and the $r b c \mathrm{~L}$ DNA sequence. Sheahan and Chase (2000) investigated the phylogenetic relationships of 36 taxa of Zygophyllaceae including 15 species of Zygophyllum L. from Africa, Australia, and south western Asia using nucleotide sequences of the plastid gene $r b c \mathrm{~L}$ and non-coding $t r n \mathrm{~L}-\mathrm{F}$ and found Zygophyllum as polyphyletic. They showed that the Zygophyllum fabago L. (the type species of Zygophyllum) nested with another Asian species Z. xanthoxylum (Bunge) Engl., whereas $Z$. simplex L. placed in a strong clade with the genus Tetraena and other Zygophyllum species, viz. Z. album L. f., Z. coccineum L., Z. cylindrifolium Schinz and Z. decumbens Delile (the last three are

${ }^{1}$ Corresponding author. Email: dalzahrani@kau.edu.sa

${ }^{2}$ Department of Biological Sciences, Faculty of Applied Sciences, Umm Al-Qura University, Makkah, Saudi Arabia. 
distributed in Saudi Arabia). The study indicated that Tetraena is nested within the large and variable Zygophyllum and reported that the Z. simplex is sister to Tetraena.

Beier et al. (2003) investigated the phylogenetic relationships of Zygophyllaceae using $\operatorname{trn} \mathrm{L}$ plastid DNA sequences and morphological data for 43 species of Zygophylloideae including the genera Zygophyllum, Fagonia, Augea and Tetraena which represent most of the morphological and geographical variations in the subfamily Zygophylloideae. They reported that the subfamily Zygophylloideae is monophyletic, whereas the genus Zygophyllum is paraphyletic, since this genus was spontaneously distributed with the genera of Augea, Tetraena and Fagonia. Based on the results of this study, Beier et al. (2003) produced a new classification for genera Tetraena and Zygophyllum, and transferred 35 species from genus Zygophyllum to genus Tetraena as new combinations. Later, Bellstedt et al. (2008) assessed the phylogenetic relationships of 53 species

of Zygophyllum in southern Africa employing the sequences of $r b c \mathrm{~L}$ and $t r n \mathrm{~L}-\mathrm{F}$ regions. They included the published sequences of the same genes for other species from different regions and the results supported the subdivision of the genus Zygophyllum into subgenera Agrophyllum and Zygophyllum. They found relatively similar results by conducting the same methods to study the relationships of Zygophyllum and Tetraena species (cpDNA sequences) and similar morphological characteristics (i.e. capsule dehiscence, seed attachment and the presence of spiral threads in the seed mucilage). These species are known from Africa and Asia. Bellestedt et al. (2008) did not agree with Beier et al. (2003) for the new classification of Tetraena and Zygophyllum. However, many authors agreed with this transfer and used the combinations proposed by Beier et al. (2003) as valid in their works, including Alzahrani (2017), Alzahrani and Albokhari (2017a, b), Azevedo (2014), Ghazanfar and Osborne (2015), Louhaichi et al. (2011), Mosti et al. (2012), Norton et al. (2009), Sakkir et al. (2012).

Tetraena is represented in Saudi Arabia by six species, two subspecies and six varieties, while genus Zygophyllum is represented by a single species, namely Z. fabago (Beier et al., 2003; Alzahrani, 2017; Alzahrani and Albokhari, 2017a, b;). Saudi Arabian Tetraena and Zygophyllum have never been included in the published phylogenetic studies. The only two studies have used RAPD markers data to study genetic variation among and within populations of some Saudi Arabian Zygophyllum taxa (Al-Arjany, 2011; Hammad and Qari, 2010). Hammad and Qari (2010) studied the genetic diversity of 12 populations of Zygophyllum coccineum, Z. album and Z. aegyptium A.I. Hosny which were collected from various locations in Egypt and Saudi Arabia using RAPD markers employing five random primers. They found that Zygophyllum coccineum revealed higher levels of genetic variation and more unique alleles than the other species and $Z$. aegyptium is genetically closely related to Z. album Later, Al-Arjany (2011) studied the molecular taxonomy of Zygophyllum simplex and Z. migahidii using of random PCR (RAPD) technology to analyse phylogenetic relationships between both species and found that these species are closely allied to each other. In the present study, phylogenetic relationships of 43 individual specimens of Saudi Arabian Tetraena and Zygophyllum species were reconstructed using combined DNA sequences data from the $r b c \mathrm{~L}$ and the $t r n \mathrm{~L}-\mathrm{F}$ regions.

\section{Materials and Methods}

\section{Selection of ingroup and outgroup}

Leaf material for 37 individual specimens of Saudi Arabian Tetraena representing six taxa were sampled in the field and from herbarium specimens listed in Tables 1 and 2. Collected specimens were deposited in KAUH (King Abdulaziz University Herbarium, Jeddah, Saudi Arabia). Sequenced data of the 10 Tetraena and Zygophyllum sequenced by Bellstedt et al. (2008) for the two regions ( $r b c \mathrm{~L}$ and $t r n \mathrm{~L}-\mathrm{F})$ were obtained from GenBank (Table 3). Three sequences of 


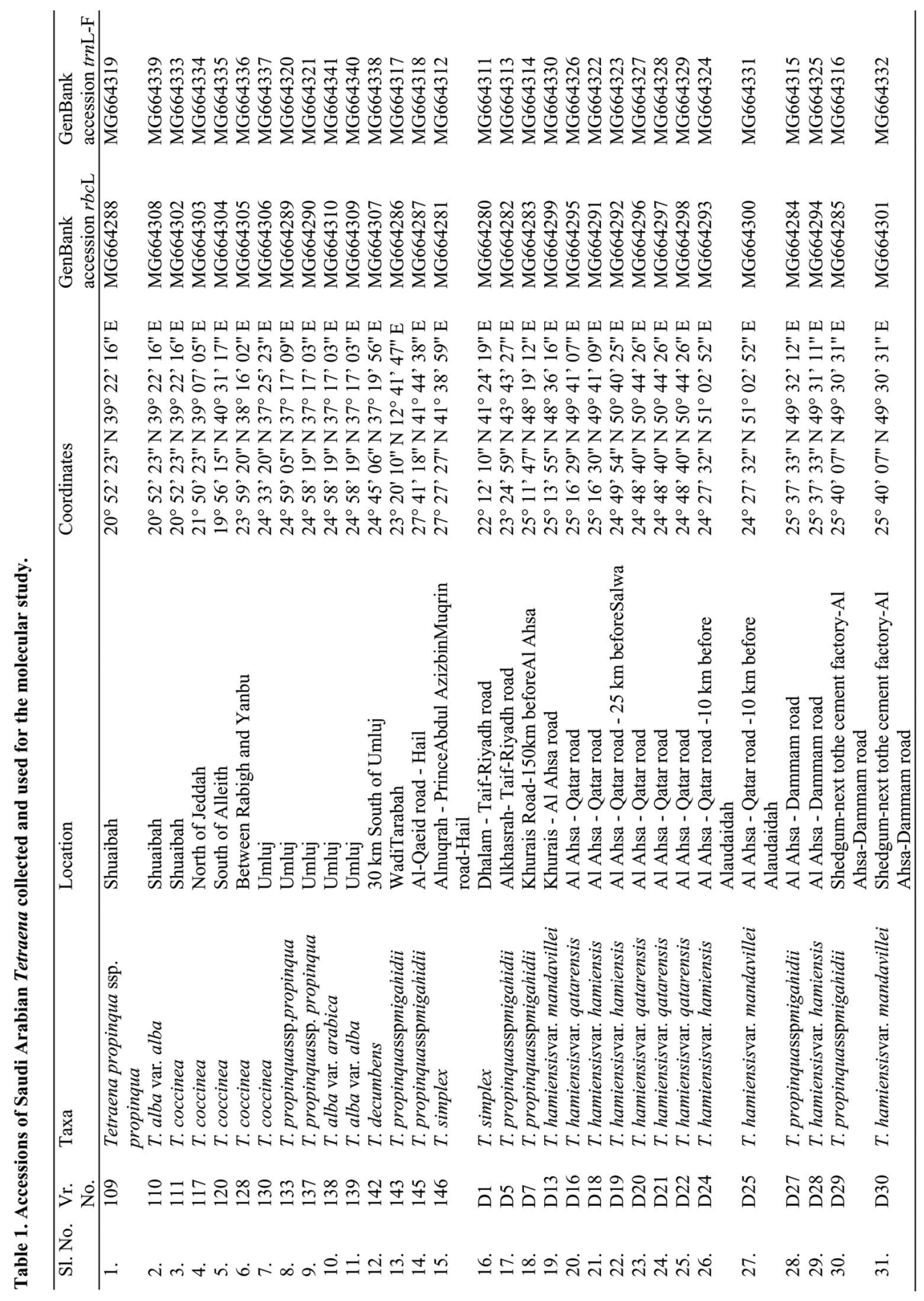


the two regions ( $r b c \mathrm{~L}$ and $t r n \mathrm{~L}-\mathrm{F}$ ) from Fagonia, the most closely related genus to Tetraena and Zygophyllum, were downloaded from GenBank to use as the out-group (Table 3). Out-group choice was based on previous work on the genus Zygophyllum (Bellstedt et al., 2008) and work on the sisters' genera to Tetraena and Zygophyllum, which is Fagonia.

Table 2. Herbarium specimens used in the present study for phylogenetic analyses.

\begin{tabular}{|c|c|c|c|c|c|c|}
\hline No. & Taxa & $\begin{array}{l}\text { Collection } \\
\text { number }\end{array}$ & $\begin{array}{l}\text { Collector's } \\
\text { name }\end{array}$ & Date & Country & Herbarium \\
\hline 1. & $\begin{array}{l}\text { Tetraena hamiensis var. } \\
\text { hamiensis } \mathrm{E} 4\end{array}$ & M. 8153 & Miller et al. & $13 / 2 / 1989$ & Yemen & $\mathrm{E}$ \\
\hline 2. & $\begin{array}{l}\text { T. hamiensis var. } \\
\text { hamiensis } \mathrm{E} 10\end{array}$ & MTA 155 & Abdullah M. & $9 / 5 / 2012$ & Kuwait & $\mathrm{E}$ \\
\hline 3. & $\begin{array}{l}\text { T. hamiensis var. } \\
\text { qatarensis } \mathrm{E} 9\end{array}$ & $21 / 2$ & Munton & $21 / 1 / 1985$ & Oman & $\mathrm{E}$ \\
\hline 4. & $\begin{array}{l}\text { T. hamiensis var. } \\
\text { qatarensis } \mathrm{K} 8\end{array}$ & 2 & Vujo, K. J. & 4/ 1979 & Bahrain & $\mathrm{K}$ \\
\hline 5. & $\begin{array}{l}\text { T. hamiensis var. } \\
\text { qatarensis } \mathrm{K} 9\end{array}$ & 10953 & Boules, L. & 29/3/1977 & Qatar & $\mathrm{K}$ \\
\hline 6. & $\begin{array}{l}\text { T. propinqua ssp. } \\
\text { migahidii E6 }\end{array}$ & 6731 & S. Collenette & $27 / 4 / 1988$ & $\begin{array}{l}\text { Saudi } \\
\text { Arabia }\end{array}$ & $\mathrm{E}$ \\
\hline
\end{tabular}

Table 3. Sequences obtained from GenBank and previously used in the analysis of Tetraena and Zygophyllum plants (After Bellstedt et al., 2008).

\begin{tabular}{lll}
\hline Taxa & GenBank accession for $r b c \mathrm{~L}$ & GenBank accession for $t r n \mathrm{~L}-\mathrm{F}$ \\
\hline Fagonia cretica L. (out group) & AJ133855 & AJ387942 \\
F. indica Burm.f. (out group) & Y15018 & AJ387943 \\
F. luntii Baker (out group) & AJ133856 & AJ387944 \\
Tetraena mongolica Maxim. & Y15027 & AJ387959 \\
Zygophyllum album L.f. & AJ133861 & AJ387963 \\
Z. coccineum L. & AJ133863 & AJ387965 \\
Z. decumbens Delile & AJ133865 & AJ387967 \\
Z. decumbens Delile var. decumbens & EF655991 & EF 656011 \\
Z. fabago L. & Y15030 & AJ387968 \\
Z. sessilifolium L. & EF655997 & EF656047 \\
Z. simplex L. & EF655984 & EF 656004 \\
Z. simplex L. & Y15031 & AJ387974 \\
Z. xanthoxylum Engl. & AJ133872 & AJ387975 \\
\hline
\end{tabular}

\section{DNA extraction}

Leaf material from field-collected plants and herbarium specimens (Tables $1 \& 2$ ) were used for DNA extraction. Leaves were dried and stored in small polythene bags at $-20^{\circ} \mathrm{C}$. Total genomic DNA was extracted using the DNeasy Plant Mini Kit (QIAGEN) following the manufacturer's protocol. The isolated DNA was stored at $-20^{\circ} \mathrm{C}$ until further use. 


\section{Choice of molecular markers}

The phylogenetic relationship of Saudi Arabian Tetraena and Zygophyllum taxa was clarified using two different chloroplast regions ( $r b c \mathrm{~L}$ and $t r n \mathrm{~L}-\mathrm{F}$ regions) based on results from the previous work on Tetraena and Zygophyllum (Beier et al., 2003; Bellstedt et al., 2008).

\section{DNA amplification}

The DNA template amplified using PCR (Polymerase Chain Reaction). The PCR used different primers to amplify the $r b c \mathrm{~L}$ and the $t r n \mathrm{~L}-\mathrm{F}$ chloroplast DNA (cpDNA) regions. The PCR amplifications for each region were carried out in $25 \mu \mathrm{l}$ reactions using $2 \mu \mathrm{l}$ of template DNA, $12.5 \mu \mathrm{l} 2 \mathrm{x}$ BioMix (Bioline), $2 \mu \mathrm{l}$ of each primer [1-10 mM] and, $6.5 \mu \mathrm{l}$ of distilled water. The $r b c \mathrm{~L}$ gene was amplified using the forward primer $20 \mathrm{bp}$ at $1 \mathrm{~F}$ (5'- ATGTCACCACAAACAG AAAC-3') and reverse primer 26bp at 1460R (5'- TCCTTTTAGTAAAAGATTGGGCCGAG-3') based on Savolainen et al. (2000a, b). The PCR conditions for the $r b c \mathrm{~L}$ amplification used the protocol as outlined in Bellstedt et al. (2008), with some modifications for some accessions. The reaction condition was $5 \mathrm{~min}$ at $94^{\circ} \mathrm{C}$, followed by 30 cycles of denaturation at $94^{\circ} \mathrm{C}$ for $30 \mathrm{~s}$, annealing temperature at $50-53^{\circ} \mathrm{C}$ for $50 \mathrm{~s}$, extension at $72^{\circ} \mathrm{C}$ for $60 \mathrm{~s}$, followed by a final extension for $6 \mathrm{~min}$ at $72^{\circ} \mathrm{C}$. The $\operatorname{trn} \mathrm{L}-\mathrm{F}$ region was amplified using the forward primer $20 \mathrm{bp}$ at c $\left(5^{\prime}-\right.$ CGAAATCGGTAGACGCTACG-3') and reverse primer f (5'-ATTTGAACTGGTGACACGAG3') based on Taberlet et al. (1991). The PCR conditions for the trnL-F amplifications were used the following program based on Bellstedt et al. (2008) which included $5 \mathrm{~min}$ at $94^{\circ} \mathrm{C}$, followed by 35 cycles of denaturation at $94^{\circ} \mathrm{C}$ for $60 \mathrm{~s}$, annealing temperature at $55^{\circ} \mathrm{C}$ for $60 \mathrm{~s}$, extension at $72^{\circ} \mathrm{C}$ for $90 \mathrm{~s}$, followed by a final extension for $6 \mathrm{~min}$ at $72^{\circ} \mathrm{C}$.

\section{PCR product purification and sequences}

PCR reactions used an automatic sequencer ABI3730XL (Macrogen Sequencing System, Korea) for purification and sequencing. For each sequence, the complementary bi-directional sequence strands were trimmed and assembled into a contig and manually edited using SeqMan software 6.1, Lasergene DNAStar 6.1 Windows 32 (DNAStar Corporation, Madison, WI, USA). All sequences were aligned automatically by BioEdit v.7.0.4.1 (Hall, 1999) or Clustal X (Thompson et al., 1997) followed by extensive manual adjustments. The two alignments were combined in one matrix using MacClade v. 4.07 (Maddison and Maddison, 2003).

\section{Phylogenetic analyses}

Maximum Parsimony: Separate analyses of $r b c \mathrm{~L}$ and $\operatorname{rn} \mathrm{L}-\mathrm{F}$ data, and of combined chloroplast ( $r b c \mathrm{~L}$ and $t r n \mathrm{~L}-\mathrm{F}$ ) data were performed to infer relationships of Saudi Arabian taxa of Tetraena and Zygophyllum using the Maximum Parsimony approach, implemented with the computer program PAUP* 4.06 b10 for 32-bit Microsoft Windows XP (Swofford, 2001). Bootstrap support analysis (Felsenstein, 1985; Felsenstein and Kashino, 1993) was implemented in PAUP* 4.06 (Swofford, 2001) to estimate the support value of individual and combined data sets with 1000 pseudoreplicates of the data using the heuristic search strategy.

\section{Bayesian analysis}

The $r b c \mathrm{~L}$ and $t r n \mathrm{~L}-\mathrm{F}$ and combined chloroplast ( $r b c \mathrm{~L}$ and $t r n \mathrm{~L}-\mathrm{F})$ were analysed to infer relationships of Saudi Arabian Tetraena and Zygophyllum plants using Bayesian inference (Mau et al., 1999; Rannala and Yang, 1996) of the separate and combined data. Bayesian analysis used the Markov Chain Monte Carlo (mcmc) simulation programme, MrBayes version 3.1.2 (Huelsenbeck and Ronquist, 2001; Ronquist and Huelsenbeck, 2003). The best fit model of molecular evolution for each individual and combined data set was selected using the Akaike Information Criterion (AIC), calculated with MrModeltest 2.2 (Nylander, 2004). The general time reversible model with 
gamma and proportion of invariable sites of $(\mathrm{GTR}+\mathrm{I}+\mathrm{G})$ was selected for all partitions as the best fit model. Five million generations were performed and 5000 trees were saved (sampling one tree per 1000 generations). Runs were repeated twice to confirm results, and typically $0.25 \%$ (c. 1250 trees) of the samples were discarded as burn-in. Majority rule consensus trees were constructed from the remaining trees to obtain posterior probabilities using PAUP* programme.

\section{Results and Discussion}

\section{Parsimony analyses}

The characteristics obtained by Parsimony Analyses of the individual and combined datasets for the taxa are summarizes in Table 4.

The trnL-F Parsimony analysis of 44 sequences yielded 100 of most parsimonious trees. All trees were saved and the strict consensus was generated (not shown). The $r b c \mathrm{~L}$ Parsimony analysis of 40 sequences yielded 100 of the most parsimonious trees. All trees were saved and the strict consensus was generated (not shown). In case of combined cpDNA, the aligned matrix of combined chloroplast ( $r b c \mathrm{~L}$ and $t r n \mathrm{~L}-\mathrm{F}$ ) sequences was $2505 \mathrm{bp}$ in length. Parsimony analysis of 44 sequences produced 100 of the most parsimonious trees. All trees were saved and the strict consensus was generated (Fig. 1).

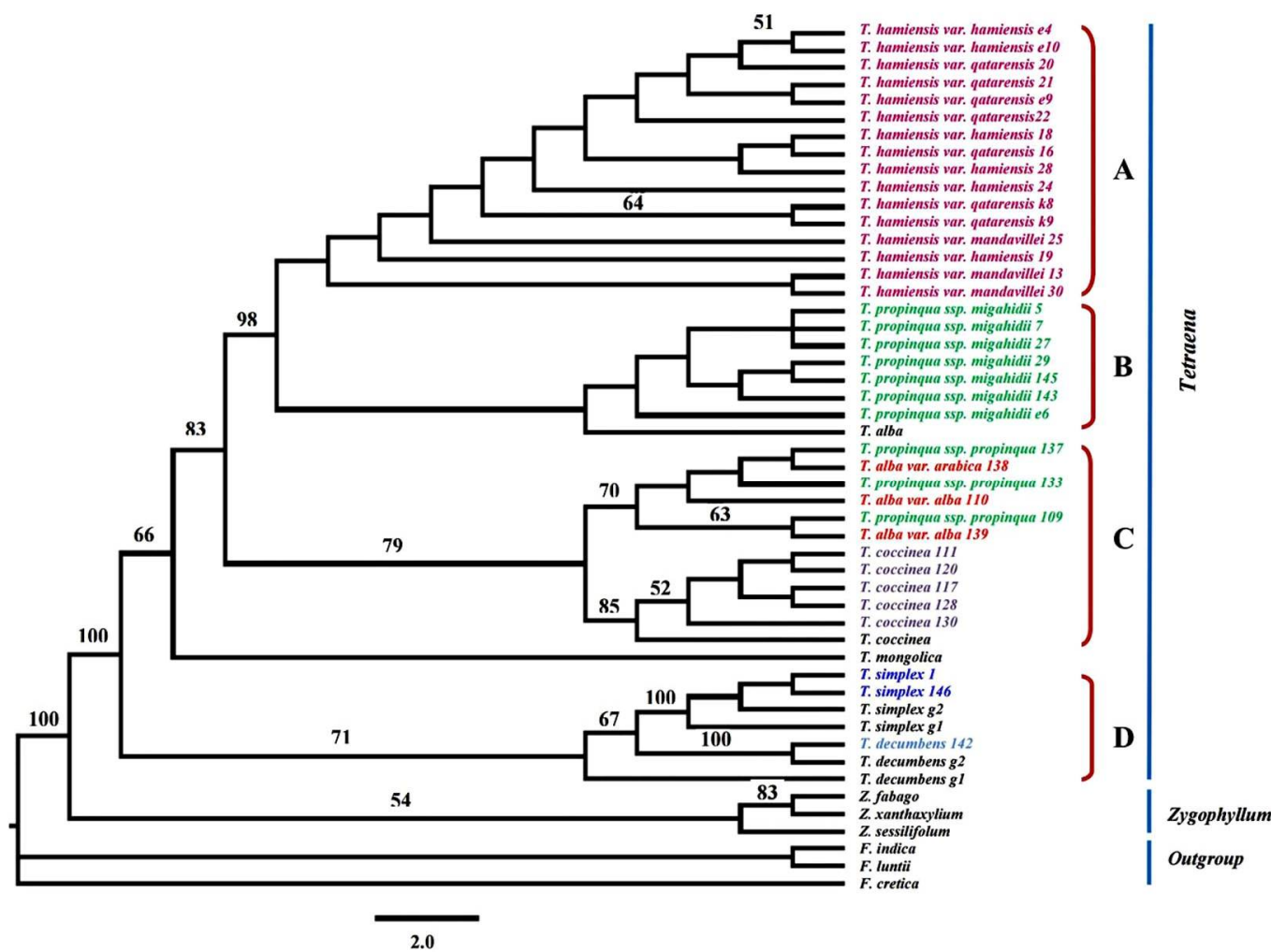

Fig. 1. One of 100 most equally parsimonious trees from analysis of the combined chloroplast of $r b c \mathrm{~L}$ and trnL-F data set, using maximum parsimony for 43 Saudi Arabian Tetraena and one Zygophyllum accessions. Numbers above nodes are bootstrap (BS) support percentage values for clades supported above a 50\% bootstrap value from 100000 replicates. Sequences of Saudi taxa are indicated with different colours and clades are indicated in letters. 


\section{Bayesian analyses}

The best fitting model retrieved by MrModeltest as the most likely evolutionary model for all individual and combined data sets was the GTR $+\mathrm{I}+\mathrm{G}$ model. Majority rule consensus trees were derived from 5000 trees from each analysis of the separate trnL-F (not shown) and rbcL (not shown) partitions and from combined chloroplast (Fig. 2) data sets. Burn-in was reached after 1250 generations for all partitions and for the combined matrix.

The represent study represents the first molecular phylogenetic study of the genus Tetraena and Zygophyllum in Saudi Arabia. Maximum Parsimony analysis and Bayesian criteria of the individuals and combined dataset of the $r b c \mathrm{~L}$ and the $\operatorname{trn} \mathrm{L}-\mathrm{F}$ chloroplast DNA sequences used to study the phylogenetic relationships of Tetraena and Zygophyllum taxa in Saudi Arabia. The most notable similarity with respect to the individual and combined analysis regarding the overall topologies of the Maximum Parsimony and Bayesian trees are quite similar.

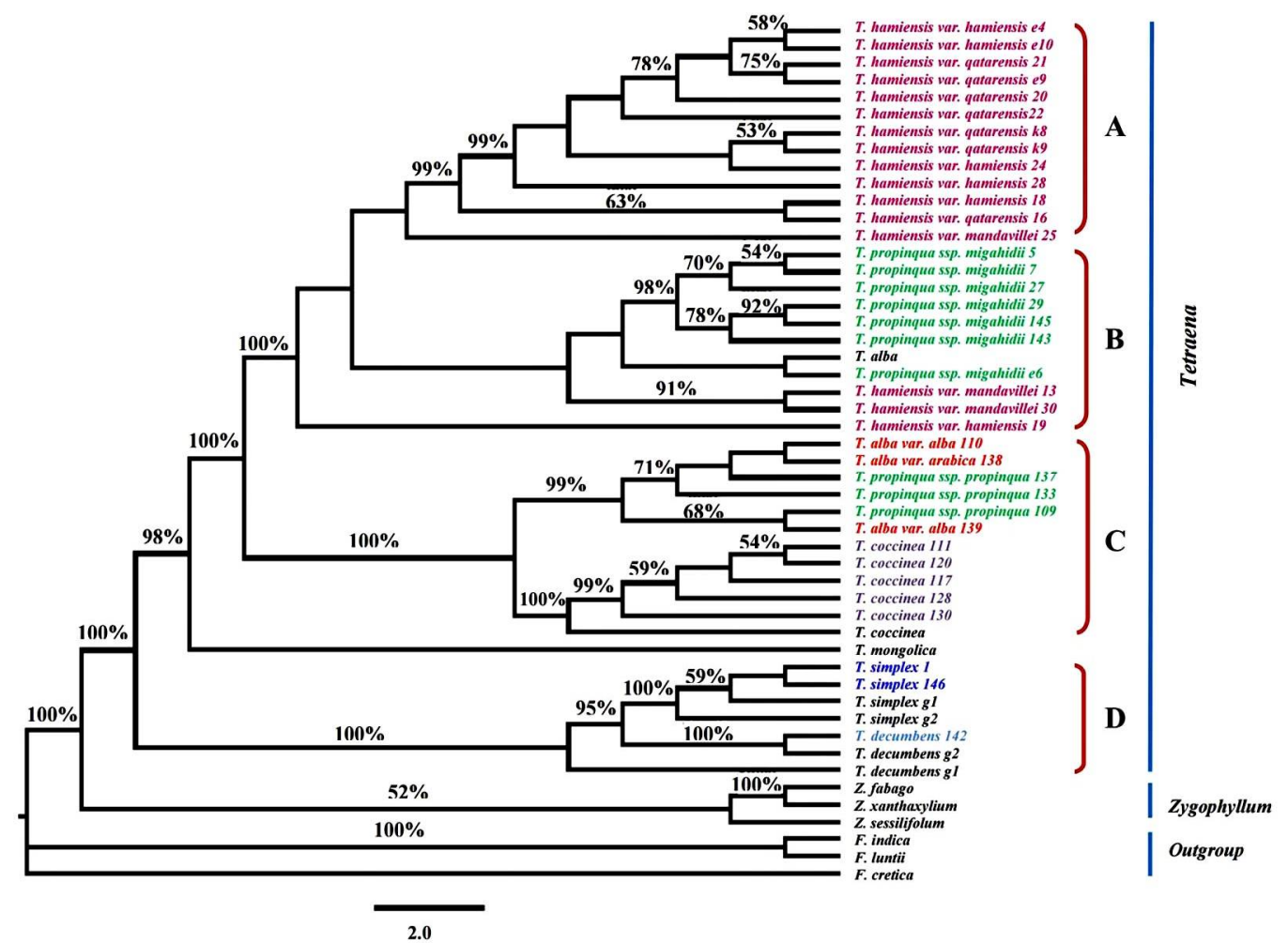

Fig. 2. Majority-rule consensus tree of the Bayesian inference based on the combined chloroplast $r b c \mathrm{~L}$ and trnL-F data set of 43 Saudi Arabian Tetraena and one Zygophyllum accessions. Posterior probability values of the nodes are indicated above the branches. Sequences of Saudi taxa are indicated with different colours and clades are indicated in letters

Each of the Tetraena and the Zygophyllum genera appear as a monophyletic group with strong support in all phylogenies. In all phylogenetic analysis, the sequences of T. mongolica Maxim. (the type species of Tetraena), downloaded from GenBank, were nested within the rest of Saudi Arabian Tetraena. This finding agrees with Sheahan and Chase (2000) and supports the new classification of Beier et al. (2003). Z. fabago and Z. xanthoxylum (Asian species) samples that 
were downloaded from GenBank are nested together in one clade as monophyletic group in all phylogenies of the Maximum Parsimony and Bayesian analysis (Figs 1 \& 2). Molecular phylogenetic results of the $r b c \mathrm{~L}$ and $t r n \mathrm{~L}-\mathrm{F}$ individually or in combination datasets analysis in this study suggested that $Z$. fabago species is differing from other samples. Moreover, the strong agreement of the findings of the morphological studies (Alzahrani, 2017; Alzahrani and Albokhari, 2017a, b;) and molecular phylogenetic analysis in this study support the classification of Beier et al. (2003) to separate Tetraena and Zygophyllum plants into two genera. Molecular

Table 4. Characteristics of the individual and combined datasets from Parsimony analysis.

\begin{tabular}{lccc}
\hline Phylogenetic information & $r b c \mathrm{~L}$ & $t r n \mathrm{~L}$ & Combined cpDNA \\
\hline Number of accession & 46 & 50 & 50 \\
Aligned length & 1434 & 1071 & 2505 \\
No. of constant characters & 1286 & 792 & 2078 \\
No. of variable characters & 56 & 134 & 190 \\
No. of informative characters & 92 & 145 & 237 \\
No. of most equally maximum Parsimony trees & 100 & 100 & 100 \\
Length of shortest trees (steps) & 194 & 457 & 673 \\
Consistency index (CI) & 0.8144 & 0.7287 & 0.7296 \\
Retention index (RI) & 0.9032 & 0.8041 & 0.8189 \\
Rescaled consistency index (RC) & 0.7356 & 0.5859 & 0.5974 \\
\hline
\end{tabular}

phylogenetic of the cpDNA analysis divided Saudi Arabian Tetraena plants into six groups: $T$. hamiensis (Schweinf.) Beier \& Thulin, T. propinqua (Decne.) Ghazanfar \& Osborne, T. alba (L. f.) Beier \& Thulin, T. coccinea, T. simplex (L. f.) Beier \& Thulin, and T. decumbens (Delile) Beier \& Thulin.

\section{Acknowledgements}

We are grateful to the curators and members of the staff of the herbaria $\mathrm{K}$ and $\mathrm{E}$ for allowing us to study and borrow specimens. Thanks are due to King Abdulaziz University, Jeddah, Saudi Arabia for providing research facilities

\section{References}

Al-Arjany, K.M. 2011. Molecular taxonomic perspective and eco-physiological variations of some species of Tribulus, Zygophyllum and Fagonia genera of family Zygophyllaceae in Saudi Arabia. Master dissertation, King Saud University, Saudi Arabia.

Alzahrani, D.A. 2017. Systematic studies on the Zygophyllaceae of Saudi Arabia: Two new subspecies combination in Tetraena Maxim. Saudi J. Biol. Sci. DOI: 10.1016/j.sjbs.2016.12.022.

Alzahrani, D.A., and Albokhari, E.J. 2017a. Systematic studies on the Zygophyllaceae of Saudi Arabia: a new variety and new variety combination in Tetraena. Saudi J. Biol. Sci. 24: 1574-1579.

Alzahrani, D.A. and Albokhari, E.J. 2017b. Systematic studies on the Zygophyllaceae of Saudi Arabia: new combinations in Tetraena Maxim. Turk. J. Bot. 41: 96-106.

Azevedo, L.B. 2014. Development and application of stressor-response relationships of nutrients. Ph.D. Thesis, Radboud University Nijmegen, the Netherlands.

Beier, B.A., Chase, M.W. and Thulin, M. 2003. Phylogenetic relationships and taxonomy of subfamily Zygophylloideae (Zygophyllaceae) based on molecular and morphological data. Plant Syst. Evol. 240: 11-39. 
Bellstedt, D.U., Van Zyl, L., Marais, E.M., Bytebier, B., de Villiers, C.A., Makwarela, A.M. and Dreyer, L.L. 2008. Phylogenetic relationships, character evolution and biogeography of southern African members of Zygophyllum (Zygophyllaceae) based on three plastid regions. Mol. Phylogenet. Evol. 47: 932-949.

Boulos, L. 1978. Materials for a Flora of Qatar. Webbia 32: 369-396.

El-Hadidi, M.N. 1977. Two new Zygophyllum species from Arabia. Publications from Cairo University Herbarium 7\&8: 327-329.

EI-Hadidi, M.N. 1980. On the taxonomy of Zygophyllum section Bipartita. Kew Bull. 35: 335-340.

Engler, A. 1931. Zygophyllaceae. In: Engler A., Prantl K. (2 ${ }^{\text {nd }}$ ed.) Die Naturlichen Pflanzenfamilien 19: 144-184. Engelmann, Leipzig.

Felsenstein, J. 1985. Confidence limits on phylogenies: an approach using the bootstrap. Evolution 39: $783-$ 791.

Felsenstein, J. and Kashino, H. 1993. Is there something wrong with the bootstrap on phylogenies? A reply to Hillis and Bull. Syst. Biol. 42: 193-199.

Ghazanfar, S.A. and Osborn, J. 2015. Typification of Zygophyllum propinquum Decne. and Z. coccineum L. (Zygophyllaceae) and a key to Tetraena in SW Asia. Kew Bull. 70: 38.

Hall, T.A. 1999. BioEdit, a user-friendly biological sequence alignment editor and analysis program for Windows. Nucleic Acids Symp. Ser. 41: 95-98.

Hammad, I. and Qari, S.H. 2010. Genetic diversity among Zygophyllum (Zygophyllaceae) populations based on RAPD analysis. Genet. Mol. Res. 9: 2412-2420.

Hosny, A.I. 1988. Genus Zygophyllum L. in Arabia. Taeckholmia 11: 19-32.

Huelsenbeck, J.P. and Ronquist, F. 2001. MrBayes: Bayesian inference in phylogenetic trees. Bioinformatics 17: 754-755.

Hussein, S.R., Kawashty, S.A., Tantawy, M.E. and Saleh, N.A. 2009. Chemosystematic studies of Nitraria retusa and selected taxa of Zygophyllaceae in Egypt. Plant Syst. Evol. 277: 251-264.

Louhaichi, M., Salkini, A.K., Estita, H.E. and Belkhir, S. 2011. Initial assessment of medicinal plants across the Libyan Mediterranean coast. Adv. Environ. Biol. 5: 359-370.

Ma, Y. and Zhang, S. 1990. Study on the systematic position of Tetraena. Acta. Phytotax. Sin. 28: 89-95.

Maddison, D.R. and Maddison, W.P. 2003. MacClade V. 4.07: Analysis of phylogeny and character evolution. Sinauer Associates, Sunderland, MA.

Mau, B., Newton, M.A. and Larget, B. 1999. Bayesian phylogenetic inference via Markovchain Monte Carlo methods. Biometrics 55: 1-12.

Mosti, S., Raffaelli, M. and Tardelli, M. 2012. Contribution to the Flora of Central-Southern Dhofar (Sultanate of Oman). Webbia 67: 65-91.

Norton, J., Abdul Majid, S., Allan, D., AlSafran, M., Böer, B. and Richer, R. 2009. An Illustrated Checklist of the Flora of Qatar. Browndown Publications, Gosport, UK. 67 pp.

Nylander, J. 2004. MrModeltest Q. Uppsala: Evolutionary Biology Centre, Uppsala University.

Rannala, B. and Yang, Z. 1996. Probability distribution of molecular evolutionary trees: a new method of phylogenetic inference. J. Mol. Evol. 43: 304-311.

Ronquist, F. and Huelsenbeck, J.P. 2003 MrBayes 3: Bayesian phylogenetic inference under mixed models. Bioinformatics 19: 1572-1574.

Sakkir, S., Kabshawi, M. and Mehairbi, M. 2012. Medicinal plants diversity and their conservation status in the United Arab Emirates (UAE). J. Med. Plants Res. 6: 1304-1322.

Savolainen, V., Fay, M.F., Albachi, D.C., Backlund, A., Van der Bank, M., Cameron, K.M., Johnson, S.A., Lledo, M.D., Pintaud, J.C., Powell, M., Sheahan, M.C., Soltis, D.E., Soltis, P.S., Weston, P., Whitten, W.M., Wurdack, K.J. and Chase, M.W. 2000a. Phylogeny of the eudicots: a nearly complete familial analysis based on $r b c \mathrm{~L}$ gene sequences. Kew Bull. 55: 257-309.

Savolainen, V., Chase, M.W., Hoot, S.B., Morton, C.M., Soltis, D.E., Bayer, C., Fay, M.F., De Bruijn, A.Y., Sullivan, S. and Qiu, Y. 2000b. Phylogenetics of flowering plants based on combined analysis of plastid $a t p \mathrm{~B}$ and $r b c \mathrm{~L}$ gene sequences. Syst. Biol. 49: 306-362. 
Sheahan, M.C. and Chase, M.W. 1996. A phylogenetic analysis of Zygophyllaceae based on morphological, anatomical and $r b c$ L DNA sequence data. Bot. J. Linn. Soc. 122: 279-300.

Sheahan, M.C. and Chase, M.W. 2000. Phylogenetic relationships within Zygophyllaceae based on DNA sequences of three plastid regions, with special emphasis on Zygophylloideae. Syst. Bot. 25: 371-384.

Swofford, D. 2001. PAUP*: Phylogenetic analysis using parsimony (*and other methods), version 4.06 b10. Sinauer, Sunderland, Massachusetts, USA.

Taberlet, P., Gielly, L., Pautou, G. and Bouvet, J. 1991. Universal primers for amplification of three noncoding regions of chloroplast DNA. Plant Mol. Biol. 17: 1105-1109.

Takhtajan, A.L. 1987. Flowering Plant. Komarov Botanical Institute, Russia.

Thompson, J.D., Gibson, T.J., Plewniak, F., Jeanmougin, F. and Higgins, D.G. 1997. The CLUSTAL_X windows interface, flexible strategies for multiple sequence alignment aided by quality analysis tools. Nucleic Acids Res. 25: 4876-4882.

Thulin, M. 1993. Zygophyllaceae In: Thulin, M. (Ed.) Flora of Somalia. Royal Botanical Gardens, Kew 1: 176-189.

Van Huyssteen, D.C. 1937 Morphologisch-systematische studien über die gattung Zygophyllum. Dissertation. Berlin.

Van Zyl, L. 2000. A systematic revision of Zygophyllum in the southern African region. Ph.D. thesis, University of Stellenbosch, Stellenbosch.

(Manuscript received on 13 June 2017; revised on 21 September 2017) 